\title{
Преглед контрастивних истраживања српског и шпанског језика у другој деценији XXI века
}

\section{Ирена М. Селаковић*}

Универзитет у Крагујевцу, Филолошко-уметнички фракултет, Катедра за хиспанистику

\section{Кључне речи: \\ контрастивна анализа контрастивна лингвистика шпански језик српски језик хиспанистика}

\section{Апстракт}

У овом раду представљамо објављена контрастивна истраживања српског и шпанског језика. Ослањамо се на досадашње прегледне радове на ову тему (Filipović, 2010; Ђуричић и Георгијев, 2015) и допуњујемо их новим подацима о радовима објављеним у периоду од 2011. до 2020. године. Захваљујући српским хиспанистима из земље и региона, постали смо богатији за велики број радова у којима се представљају сличности и разлике ова два језика на различитим језичким нивоима. Обрађено је 90 научних радова, 6 докторских дисертација и 2 научне монографије. Циљ је био испитивање интересовања из области контрастивне лингвистике српског и шпанског језика и разлика и достигнућа у односу на претходна истраживања. Потрудили смо се да сагледамо ширу слику и утврдимо које лингвистичке области би требало темељније обрадити и испитати. Због свега наведеног, рад може бити од велике користи за оне који се баве теоријско-лингвистичким и примењенолингвистичким истраживањима српског и шпанског језика. Ради боље прегледности и систематизације, истраживања су подељена према тематским областима, а на крају истраживања налази се обједињена листа референци. (примљено: 14. марта 2021; прихваћено: 3. јула 2021) www.anali.fil.bg.ac.rs

\section{АНАЛИ

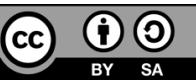

Филолошко-уметнички факултет
Универзитета у Крагујевцу
Катедра за хиспанистику
Јована Цвијћћ бб
34000 Крагујевац, Србија
irena.selakovic@filum.kg.ac.rs

Филолошко-уметнички факултет 34000 Крагујевац, Србија irena.selakovic@filum.kg.ac.rs 


\section{1. Увод}

Овај рад представља својеврстан наставак прегледа контрастивних истраживања која су објавиле Филиповић (2010) и Ђуричић и Георгијев (2015). Њихови радови су од кључног значаја за све оне који се баве контрастивним истраживањима српског и шпанског језика због тога што садрже комплетну библиографију која може бити од користи како младим научницима хиспанистима, тако и познатим лингвистима и професорима. Филиповић (2010) контрастивна истраживања дели на теоријске и апликативне групе, са посебним освртом на резултате језичких контаката и сефардске студије. Ауторка на самом почетку нуди кратак осврт на историју контрастивне лингвистике фокусирајући се са једне стране на теоријску лингвистику и описивање језичких феномена, а са друге на теоријско-методолошка истраживања у оквиру теорије о усвајању и учењу страних језика. Истраживањем су обухваћени радови на српском и шпанском језику објављени закључно са 2009. годином које је ауторка критички сагледала и представила. Приказане су главне тачке интересовања хиспаниста и србиста у нашем региону до тада.

Ђуричић и Георгијев (2015) се надовезују на чланак Филиповић (2010) и коментаришу радове контрастивне лингвистике српског и шпанског језика закључно са 2013. годином. Истраживања у њиховом раду су подељена на лингвистичке области, и то на фонетику и фонологију, морфосинтаксу, семантику, лексикологију и фразеологију.

Методологија коју користе ауторке Ђуричић и Георгијев (2015) на основу које врше поделу представља методологију коју ћемо користити као полазиште у нашем раду. Сматрамо да се радови контрастивних истраживања не могу одвојити од радова који се баве традуктолошким анализама, те да је веома прикладно да се нађу на заједничкој листи. Из тог разлога смо радове разврстали на следеће области: 1) граматика; 2) лексикологија; 3) традуктологија и 4) прагматика.

У оквиру нашег истраживања представићемо објављене радове контрастивне лингвистике српског и шпанског језика у другој деценији XXI века, односно од 2011. до 2020. године. Циљ нам је да утврдимо да ли су хиспанисти остали при пређашњим интересовањима и шта је то што се променило у односу на ранија истраживања. Такође, на основу досадашњих филолошких достигнућа из области контрастивне лингвистике српског и шпанског језика, желимо да испитамо које лингвистичке области нуде још простора за компаративне студије. На крају истраживања налази се обједињена листа референци.

\section{2. Контрастивна истраживања српског и шпанског језика из обла- сти граматике}

Приликом овог истраживања побројали смо велики број радова који обрађују различите теме из области граматике, а можемо их поделити на две групе: 1) фонетско-фонолошка и 2) морфосинтаксичка истраживања.

Огроман допринос контрастивној анализи у оквиру поља фонетике и фонологије пружили су радови ауторке Изабеле Бељић. Ова ауторка се бавила 
транскрипцијом шпанске ламино-алвеопалаталне безвучне африкате графије ch на српски језик. На основу досадашње праксе, запажена је неусаглашеност приликом транскрипције и представљена разлика између српских безвучних африката ћ и ч. Закључак до којег је ауторка дошла јесте да шпанском африкату ch у шпанском језику по својој природи више одговара африкат ћ у српском, те да би досадашња правила требало ревидирати (Beljić, 2012).

Контрастирањем безвучних гласова бавила се $и$ ауторка Кузмановић-Јовановић која је изучавала безвучни фрикатив $x$ у шпанском и српском језику (Кузмановић-Јовановић, 2012).

Бељић (2013) представља проблематику изговарања и транскрибовања имена из шпанског језика на српски. Ауторка и у овом раду указује на потребу актуелизације и усаглашености правила транскрипције. Велики значај даје изговору полазног, односно шпанског језика, који би требало да диктира начин транскрибовања имена.

У наредном истраживању ауторка Бељић наставља да се бави проблематиком транскрипције шпанских имена и предлаже реформу у облику минималних промена већ утврђених правила зарад побољшања квалитета транскрипције. Бељић сматра да познатије речи које су увелико прихваћене у свом „неправилном“ облику не треба мењати, али да оне мање познате треба модификовати уз помоћ правила која су изложена у њеном раду. Значај ових контрастивних истраживања у области фонетике и фонологије огледа се у систематизацији јединствених правила која ће олакшати процес транскрипције власитих имена у будућности (Beljić, 2016).

Питањем прилагођавања речи из шпанског језика на српски бавила се и ауторка Јелена Рајић. У фокусу њеног истраживања су властита имена, именице, топоними, те историјски и културни термини. У чланку се на основу Правописа српског језика указује на неправилну употребу речи у српском језику које су пореклом из шпанског. Ауторка закључује да је то последица фонолошких, ортографских и морфолошких промена на основу којих се речи прилагођавају језичком систему у који се преносе (Rajić, 2016).

Коначно, Бељић, Ковачевић Петровић и Донић (2019) у оквирима преводне књижевности и стручне литературе испитују правописне норме везане за транскрпцију шпанских графема ch $и$ z на српски језик. Аутори након исцрпног приказа развоја хиспанистике у Србији долазе до закључка да су најпогоднији парњаци овим графемама српски гласови ћ и с.

У претходној деценији неколико аутора бавило се контрастивним истраживањима српског и шпанског језика на пољу морфосинтаксе.

Контрастирање глаголских времена у српском и шпанском језику проучавала је ауторка Ђуричић (2014). Циљ њеног рада било је испитивање разлике између шпанског простог/несвршеног футура (futuro simple/imperfecto) и футура првог у српском језику. Ауторка је дошла до закључка да су ова два времена слична када се њима исказује будућа радња. Међутим, шпански прост футур не користи се искључиво за представљање будућности, већ и за исказивање мо- 
далности и вероватноће, па у тим ситуацијама не постоје преводни еквиваленти у српском језику у облику футура првог.

1Глаголским перифразама са герундом и њиховим преводним еквивалентима у српском језику бавила се Петровић (2014). Ауторка је дошла до закључка да перифразама са герундом које исказују трајање радње у шпанском, у српском језику одговарају глаголи несвршеног глаголског вида због тога што опозиција свршеност/несвршеност глаголског вида у шпанском језику не постоји.

Глаголски вид у српском и шпанском језику обрађивале су и ауторке Пејовић и Николић (2011) у свом заједничком раду. У жижи њиховог истраживања био је процес настанка свршених глагола.

Проблематику глаголског вида представила је и ауторка Георгијев (2014) која је испитивала разлику између темпоралности и аспектуалности српског и шпанског језика на основу разлике у глаголским временима. Контрастирање језика представљено је кроз призму слагања времена и граматичку категорију аспекта или вида. Ауторка истиче да српски језик познаје категорију вида и користи мање глаголских времена за исказивање прошлих радњи од шпанског. Са друге стране, говорници штанског језика смештају прошле радње на временску осу у односу на неки конкретан догађај у прошлости и служе се слагањем времена. С обзиром на то да се ради о два различита језичка феномена, овај рад је од велике користи и за наставу шпанског као страног језика.

Маркос Бланко (Marcos Blanco, 2019) се такође бавио контрастивном анализом темпоралности и аспектуалности у глаголским системима шпанског и српског језика. Међутим, у односу на остале објављене чланке српских хиспаниста аутор у средиште интересовања поставља контекст у коме се одвија конверзација на српском језику. Маркос Бланко запажа да је значења шпанских облика могуће уврдити уколико се облици на српском језику анализирају заједно са контекстом. Због оваквог приступа рад је од великог значаја у области примењене лингвистике.

Пејовић (2018в) је изучавала употребу имперфекта у шпанском језику у односу на српски на основу темпоралности и аспектуалности. Закључци показују да је у српском језику неколико глаголских времена еквивалент шпанском имперфекту због тога што је он у српском готово ишчезао из употребе. Шпански имперфекат се у великом броју случајева, уместо имперфектом, преводи перфектом, презентом, потенцијалом или футуром у српском језику (Пејовић, 2018в).

Контрастивним морфосинтаксичким истраживањима допринела је и ауторка Зечевић-Крнета својом докторском дисертацијом (2017) у којој је истраживала употребе одређеног члана у шпанском као страном језику. Научни допринос огледа се у томе што је тема обрађена на основу анализе грешака код говорника српског, те представља погодан материјал и за наставнике шпанског као страног језика.

Исту проблематику испитивала је и ауторка Рубињони Стругар. Она је у својој монографији представила карактеристике и употребу одређеног члана 
као дела језичког феномена детерминације који у српском језику није морфолошки представљен (Rubinjoni Strugar, 2018). Ова монографија је такође намењена свима онима који уче шпански као страни језик.

Рубињони Стругар обрађује тему одређеног члана и у једном од радова у коме на основу контрастивне анализе и анализе грешака врши истраживање на одређеној групи студената Катедре за иберијске студије Филолошког факултета Универзитета у Београду. У фокусу рада су проблеми на које испитаници наилазе приликом учења шпанског као страног језика (Rubinjoni Strugar, 2019).

Питању евиденцијалности посветила се ауторка Рајић која је истраживала евиденцијалне стратегије у српском и шпанском језику на основу језичког кодирања информација (Рајић, 2012). Ауторка закључује да говорници ова два језика углавном исказују евиденцијалност уз помоћ лексичких или синтаксичких облика који су у великом броју случајева условљени контекстом.

Рајић (2015) у наредном истраживању упоређује начине за исказивање евиденцијалности у српском и шпанском језику. Захваљујући примерима из Корпуса савременог српског језика (СрпКор) и Актуелног шианског референтног корпуса (CREA) ауторка побројава све језичке изразе који имају евиденцијалну вредност и испитује њихове сличности и разлике.

Рајић (2019) испитује глаголе промене hacerse, volverse и ponerse и њихове еквиваленте у српском језику. Глаголи промене представљају много сложенији систем у шпанском него у српском језику, а ауторка детаљно анализира употребу наведених глагола на основу одговарајућег корпуса. Закључци до којих долази показују да глагол постати у српском језику има информативно значење и означава само процес постојања, док се уз глаголе промене у шпанском језику значење представља из субјективне перспективе и везано је за комуникативну намеру.

Танасијевић (2017) је изучавао употребу глагола ser и estar у шпанском језику и њихове еквиваленте у српском. Аутор долази до закључка да ови глаголи у шпанском језику имају тројаку употребу, односно да могу бити основни, копулативни или помоћни глаголи, којима је најадекватнији заједнички еквивалент у српском језику глагол бити. Овом језичком питању је веома битно темељно приступити од самог почетка учења језика, првенствено зато што у српском језику постоји само један глагол бити, који може бити или пунозначан или непунозначан. То често збуњује ученике јер нису сигурни за који глагол да се определе у шпанском језику, за ser или estar.

На основу свега реченог, закључујемо да су у претходној деценији хиспанисти у својим радовима велику пажњу посветили граматичким проблемима у српском и шпанском језику. Са једне стране, фонетско-фонолошка проучавања се првенствено везују за ревидирање утврђених правила транскрипције и правилног изговарања гласова. Са друге стране, морфосинтаксичка проучавања теже испитивању и упоређивању глаголских система ова два језика. 


\section{3. Контрастивна истраживања српског и шпанског језика из обла- сти лексикологије}

Лексикологија је без сумње област која је највише истраживана у оквиру контрастивних проучавања српског и шпанског језика.

Као и у претходној, и у овој деценији велики допринос контрастивним истраживањима фразеолошких јединица српског и шпанског језика дала је ауторка Анђелка Пејовић истраживањем великог опсега фразеолошких питања са посебним освртом на проблеме превођења. Ауторка у једном раду представља поредбене фразеологизме у српском и шпанском језику истичући да се у великој мери разликују од стандардних идиоматских израза. Закључак рада је да такви изрази омогућују стварање нових парадигми у којима се запажа висок степен продуктивности (Пејовић, 2011а).

Ауторка Пејовић касније изучава стереотипне конструкције за исказивање компарације у шпанским и српским фраземима. На основу спроведене анализе ауторка потврђује да српски обилује поређењем по односу једнакости, док се говорници шпанског језика првенствено служе компаративним конструкцијама супериорности (Pejović, 2011c).

Даље, Пејовић (20116) испитује превод шпанских глаголских идиома на српски језик у романима Мигела Делибеса, а циљ рада је да укаже на проблеме превођења фразема. На основу исцрпне анализе и упоређивања различитих превода, ауторка закључује да не постоји велики број тоталних еквивалената међу глаголским идиомима. Такође, ауторка напомиње да преводиоци углавном посежу са парафразирањем на основу смисла полазног фразеологизма.

У једном од својих радова уз помоћ контрастивне анализе Пејовић испитује фраземе у српском и шпанском језику повезане с појмовима за храну (Рејović, 2012).

У наредним истраживањима Пејовић (2013a, 2013c) представља фразеолошке јединице (углавном паремије и идиоме) кроз призму етичких и естетичких принципа попут поштења, солидарности, милости, поштовања, правде, истине, марљивости, скромности и лепоте. Оно што је заједничко и за шпански и за српски језик јесте да промене које се дешавају у друштву утичу на модификовање традиционалних вредности, а то све има директног утицаја и на различите облике језичког изражавања.

Пејовић је у једном истраживању представила лажне пријатеље у српској и шпанској фразеологији. Лажни пријатељи су подељени на три категорије: 1) фраземи исте структуре а делимично различитог значења, 2) фраземи сличне структуре а различитог значења, 3) фраземи делимично сличне структуре, истог значења а различите употребне вредности (прагматички лажни пријатељи) (Пејовић, 20136).

Нешто касније Пејовић испитује вишезначност у фразеологији и анализира степен полисемије међу фразеолошким јединицама српског и шпанског језика. Рад полази од идеје да и фраземи, попут лексема, могу имати широк спектар значења, а закључак је да је то најчешће случај са глаголским изразима, 
најбројнијим у фразеологији. Оно што остаје као идеја за даља истраживања јесте испитивање да ли се у шпанском и српском језику нова значења фразема развијају по истим принципима (Пејовић, 2014а).

У оквиру фразеолошких истраживања Пејовић је пажњу посветила и бојама. Ауторка у једном раду испитује преко 260 фразеологизама са хроматизмима ирно и бело у српском и шпанском језичком систему. Запажања до којих долази показују висок степен подударности међу језицима који се пореде, иако је српски богатији када је реч о овим фразеолошким јединицама. Ауторка је такође показала да црна и бела боја не морају нужно бити прави антоними, већ да је супротност црној веома често ружичаста, коју одликује позитивно значење (Пејовић, 2013г).

У другом раду који такође обрађује проблематику боја, на корпусу из различитих речника ауторка анализира фраземе са бојама као главним конституентима и истражује њихову конотацију. Након детаљне анализе, она потврђује закључак из претходног рада на основу којег је ружичаста једина боја која никада нема негативну конотацију (Pejović, 2014b).

Исте године Пејовић се контрастивно бавила и називима националности и професија у српском, односно шпанском језику. Примери су преузети из фразеолошких и једнојезичних речника, а велики значај рада се огледа у томе што анализи нису подвргнути само фраземи већ и паремије у ужем смислу (пословице и изреке). Истраживање показује да су вредности ових израза углавном негативне, као и да у великом броју случајева доприносе стварању стереотипа и предрасуда (Пејовић, 2014в).

Кроз призму фразеологије Пејовић је истраживала и естетичке вредности испитујући фраземе који представљају женску и мушку лепоту, како у физичком тако и у духовном смислу. Захваљујући овом истраживању ауторка је дошла до закључка да се на основу ових израза лепота углавном пореди са добротом и другим позитивним људским особинама (Pejović, 2014d).

Пејовић анализира и паремије у српском и шпанском језику у оквирима етнолингвистичких садржаја. Акценат се ставља на паремије које преносе одређено животно искуство или приказују промене код нових генерација у односу на њихове претке. Примери који то најбоље показују јесу паремије са лексемом хлеб, родбинским односима, одевним предметима и лепотом углавном везаном за жене. Различите друштвене и историјске околности у Шпанији и Србији показале су неуравнотеженост између анализираних паремија (Пејовић, 2014д).

Пејовић (20156) се бавила и процесом фразеологизације током којег се одређене пословице своде на фраземе. Ауторка долази до закључка да паремије често трпе модификације, али да то не утиче на њихов нестанак из језика већ само на промену облика.

Посебно морамо издвојити монографију Контрастивна фразеологија шианског и српског језика (2015а) у којој су представљена дотадашња теоријска и емпиријска истраживања професорке Анђелке Пејовић. Монографија у окви- 
ру четири поглавља (преглед фразеолошких истраживања, лексичко-семантичко истраживање, семантичко истраживање и етнолингвистичко разматрање паремија и фразема у шпанском и српском језику) анализира преко 1000 фразема и пословица како на српском, тако и на шпанском језику.

У неколико радова Пејовић је истраживала шпанске идиоме и концептуалне метафоре. У једном чланку бави се идиомима ексцерпираним из шпанских фразеолошких речника, који у својој структури садрже лексеме срие / corazón и душу / alma. Закључак рада је да се ови изрази углавном повезују са позитивним осећањима (Pejović, 2016а).

У наредном истраживању Пејовић (20166) се бави идиомима са конституентом крв / sangre. На основу семантичке и концептуалне анализе и уз помоћ анализираног корпуса ауторка уочава заступљеност три појмовне метафоре: КРВ JE ЖИВО БИЋЕ (ЧОВЕК), КРВ ЈЕ (ВРЕДАН) ПРЕДМЕТ И КРВ ЈЕ МАТЕРИЈА (ВОДА). Присутан је већи број фразеологизама у српском језику, а пронађена је подударност између фразема са конституентима крв и млеко, који имају негативно значење (Пејовић, 20166).

Што се тиче односа културема и националних фразеологизама, ауторка је у једном раду одлучила да испита у којој мери културеме можемо поистоветити са устаљеним јединицама које су карактеристичне за одређену културу, односно заједницу (Пејовић, 2016в).

Пејовић се бавила и истраживањем пословица. Међутим, оно што је другачије у односу на претходна истраживања јесте да се поред контрастивне анализе шпанског и српског уводи и трећи језик, хебрејско-шпански. На великом броју примера испитују се и упоређују пословице споменутих језика које су везане за породичне односе, првенствено за ликове оца, мајке, деце, браће и сестара, свекрве, снаје, маћехе, итд. (Рејović, 2018а).

У оквир још једног истраживања у коме се анализирају пословице, ауторка Пејовић укључује афоризме и антипословице којима се често исказује експресивна, апелативна, афективна, хумористичка и лудичка функција. У раду се запажа да су те функције наглашене углавном када се израз модификује и употреби у одговарајућем контексту, па тада делује као језички инструмент којим се порука појачава или истиче (Пејовић, 20186).

Ауторка Пејовић је у свој научни опус укључила и испитивање лексема и фразеологизама из српског и шпанског језика који су везани за укусе (слатко, слано, горко и кисело) (Рејоvić, 2019).

Велики допринос контрастивним проучавањима на пољу лексиколошких и фразеолошких истраживања пружила је и ауторка Анета Тривић. У једном раду она испитује соматске фразеологизме са конституентом срие/corazón. На основу степена фразеолошке еквиваленције коју нуди Корпас Пастор (тотална, парцијална, нулта и категорија лажних пријатеља), Тривић анализира фразеологизме са компонентом срие у шпанском и српском језику и долази до закључка да на овом нивоу лингвистичке анализе шпански и српски језик имају много сличности (Trivić, 2011). 
У наредном истраживању Тривић из теоријске перспективе сагледава $и$ упоређује фразеолошке јединице у српском и шпанском језику бавећи се њиховом деноминацијом и класификацијом (Тривић, 20136).

На основу концептуалне и традуктолошке анализе Тривић затим испитује шпанске и српске идиоме са временском вредношћу усредсређујући се на оне изразе који исказују прошле, садашње и будуће радње, као и учесталост или брзину неке акције. Проблем превођења не представљају изрази који се екплицитно везују за одређен концепт времена као што је време, дан, ноћ, година, него се он јавља код фразеологизама који преносе слику без позивања на неки временски концепт (Trivić, 2014).

Даље у својим радовима Тривић пажњу посвећује соматским фразеологизмима, првенствено онима са конституентима глава и око (Trivić, 2013a, 20136).

Ауторка Тривић је 2015. године одбранила докторску дисертацију под називом Лексичко-семантичка анализа соматизама у фразеологији савременог шпанског и српског језика: контрастивни приступ (Тривић, 2015а). Циљ истраживања био је анализа на лексичко-семантичком и концептуалном нивоу соматских фразеологизама с компонентама глава / cabeza, око / ојо, pука / brazo и шака / тапо, као и систематизација и одређивање степена преводне еквиваленције. Соматизми су распоређени на три концептуална поља: 1) радње које човек врши; 2) апстрактне појаве које га окружују; 3) карактеристике које му се приписују.

Тривић се у још једном раду бавила преводном еквиваленцијом, овога пута анализирајући мимички фразеологизам отворити очи / abrir los ojos. У раду се у оквиру теоријског дела представљају постулати контрастивне лингвистике и преводне еквиваленције у фразеологији. Централни део посвећен је анализи споменутих фразеологизама. Полазна тачка биле су њихове лексикографске дефиниције; међутим, на основу контекстуализованих примера уочава се и њихова прагматичка улога која је од великог значаја за комуникативну улогу ових фразеологизама (Тривић, 20156).

Исте године, у следећем раду, ауторка са семантичког и функционалног гледишта испитује соматске фразеологизме који се састоје из конституената рука / тапо. Теоријска основа овог рада почива на теорији когнитивне лингвистике, а методом концептуалне анализе фразеологизми се сврставају у концептуална поља на основу придевских парова: 1) вешт, спретан / неспретан; 2) заузет / беспослен, вредан / лењ; 3) успешан / неуспешан; 4) добар / лош, поштен / непоштен; 5) дарежљив / тврдица, лопов; 6) строг, суров / покоран, немоћан; 7) остале карактеризације (Тривић, 2015в).

Насупрот многим радовима контрастивне фразеологије који се баве сличностима у међујезичким системима, ауторка у једном раду испитује разлике соматских фразеологизама српског и шпанског језика. Како Тривић истиче, ова врста фразема није условљена културолошким феноменима који могу представљати проблем приликом превођења, већ је настала захваљујући телесном искуству (Тривић, 2016а). 
Тривић се такође бавила фразеолошким разликама идиома на основу сличности метафоричке конструкције. Ауторка разврстава неподударности на три основне категорије по Добровољском (2005): 1) привидна еквиваленција (лажни пријатељи); 2) међујезички квазисиноними и 3) асиметрична полисемија (Тривић, 20166).

Тривић нешто касније испитује месну и временску адвербијалну функцију соматских фразеологизама и утврђује да је на основу њих просторна блискост присутнија у односу на просторну удаљеност (Тривић, 2017а).

У наредном истраживању Тривић детаљније проучава област времена на основу соматских фразеологизама који често лексикализују различите временске секвенце (Тривић, 20176).

Ауторке Пејовић и Тривић имају неколико зејдничких радова. У једном од њих су истраживале концепт времена у оквирима српске и шпанске фразеологије. На примерима ексцерпираним из фразеолошких речника ауторке покушавају да уоче сличности и разлике између фразема. Истраживање показује да највише сличности има међу фраземима прилошког карактера, док се највише разлика везује за именске, придевске и глаголске фраземе (Pejović/Trivić, 2012).

У другом раду су Пејовић и Тривић (2018) пажњу посветиле идиосинкразији кроз призму фразеологије на дијахронијском нивоу. На основу различитих културолошких аспеката ауторке представљају фразеолошке јединице српског и шпанског језика. Реч је о конструкцијама које или немају свој еквивалент у језику са којим се пореде или се у датим културама не користе исти ентитети који описују те феномене. Ауторке су запазиле да се кроз српске фраземе може уочити утицај отоманске културе под којом је Србија била пет векова (Pejović/ Trivić, 2018).

У још једном заједничком раду, ауторке представљају фразеолошке јединице на основу њихове експресивности, једног од њихових најважнијих обележја. У раду се фразеолошке јединице деле према синтаксичким функцијама које врше на: 1) карактеризаторе (дескриптори, атрибутиви) и 2) фразео-прагматичке формулације (Тривић/Пејовић, 2020).

Тривић и Лончар (2020) се баве контрастирањем идиоматских конструкција на материјалу из три језика: шпанског, српског и хрватског. Предмет истраживања су неправилности заступљене у овим изразима које су ауторке поделиле на формалне, односно граматичке, и семантичке, везане за оне чији конституенти не граде смислену целину. Ауторке закључују да ове конструкције у сва три језика служе за исказивање високог степена експресивности.

Голак и Пејовић (2018) такође контрастирају три језика - руски, српски и шпански. Ауторке испитују представљање чула укуса и долазе до закључка да се кроз његову симболику може уочити начин на који човек спознаје свет око себе. Укуси (слатко, горко, кисело и слано) су испитани кроз призму фразеолошких јединица. Уочен је већи степен сличности међу словенским језицима, односно између српског и руског, него између српског и шпанског или руског и шпанског. Оно што је другачије у односу на остале радове у којима се пореде 
три језика јесте чињеница да је овај рад написан на руском језику, односно трећем језику који се уводи.

Танасијевић (2019) испитује фразеолошке јединице са конституентом бог у савременом шпанском и српском језику. На основу контрастивне анализе и преводних еквивалената аутор долази до закључка да постоји велика подударност у два анализирана језика када је реч о овим фраземима. Разлог за то је, како аутор истиче, вековни утицај религије на готово све животне сфере људи.

Рајић (20146) анализира хиспанизме и лузизме у савременом српском језику. Како ауторка наводи, процес позајмљивања обухватио је само лексички домен и семантичко-појмовне особености традиције и културе Шпаније, Португалије и земаља Средње и Јужне Америке. Због тога је циљ рада био да на основу социокултурног аспекта утврди степех заступљености хиспанизама $и$ лузизама у нашем језику. Закључак до којег Рајић долази јесте да је њихова употреба у српском углавном присутна у новинско-публицистичким текстовима или рекламном и коменрцијалном садржају, као и да се углавном интегришу посредно, преко других језика, модификујући своја лексичко-семантичка својства. Овај податак не значи да су мање битни од осталих изама, већ да њихова употреба у језику доприноси његовој динамичности и експресивности.

Ћирић (2016) се бави истраживањем појма времена у српском и шпанском језику на основу когнитивног механизма појмовне метонимије коју аутор сматра релевантнијим когнитивним обрасцем од појмовне метафоре.

Петровић и Тулимировић (2014) се у свом коауторском раду баве придевским паронимима у српском и њиховим еквивалентима у шпанском језику. Ауторке запажају да група или пар паронима у једном језику нема увек одговарајуће еквиваленте у шпанском, као и да се придевски пароними у шпанском често третирају као синоними.

У још једном заједничком раду ауторке се са теоријске тачке гледишта баве устаљеним фразама (шп. fórmulas rutinarias) у српској и шпанској фразеологији. Показују статус који ови изрази имају у многобројним студијама и долазе до закључка да је шпански језик у том погледу богатији (Petrović/Tulimirović, 2016).

Петровић Гујаничић (2020) испитује како су дефинисане паремије у општим и терминолошким речницима српског и шпанског језика и анализира да ли паралеле између њих постоје или не.

Георгијев у својим радовима $(2015,2018 b)$ испитује метафоре о умирању и смрти у српском и шпанском језику на основу когнитивних културних модела, док у каснијим радовима (2019а, 20196) пажњу посвећује етнолингвистичком приступу теми смрти у српским и шпанским паремијама анализирајући пословице на основу хришћанских уверења и традиције.

Ауторка Георгијев се бавила и појмовима љубави и новца у српским и шпанским паремијама. На основу квалитативне социолингвистичке и компаративне методе ауторка испитује однос између ова два концепта на примеру српских и шпанских паремија у којима се уочавају особености културолошких елемената 
једне и друге земље. Ауторка долази до два различита виђења односа између љубави и новца. У првом случају финансије не утичу на љубав, а у другом љубав зависи од материјалне ситуације (Георгијев, 2017).

Ауторка Георгијев је 2018. године одбранила докторску дисертацију под називом Когнитивни културни модели: ,ьубав' у српским и шпанским паремијама (Георгијев, 2018а). Циљ истраживања био је допринос бољем разумевању српског и шпанског језика и културе на основу поређења културних модела у паремиолошким системима ова два језика. На основу анализираних паремија истраживање је показало велику сличност у погледу концептуализације романтичне љубави.

Николић и Шарчевић (2012) се на примеру три језика, српског, шпанског и енглеског баве концептуалним метафорама повезаним са емоцијом страха. На основу анализе датих идиома ауторке представљају повезаност ових језика кроз културолошке елементе.

У још једном заједничком раду придружује им се и ауторка Тривић; оне испитују метафору у оквиру когнитивне лингвистике такође у српском, шпанском и енглеском језику. Ауторке анализирају метафоре користећи Ковечешов табеларни приказ пресликавања метафора и долазе до закључка да искуства људи утичу на менталну концептуализацију. На основу анализе изворних и циљних домена уочено је мимоилажење културолошких аспеката код ова три народа, али примећене су и сличности менталних представа (Николић и др., 2012).

Николић се у оквиру лексиколошких истраживања бави прегледом неологизама у шпанској и српској лингвистици полазећи од термина неологија и неологизам преко различитих приступа проучавању ових јединица (Николић, 20206).

У још једном раду који обрађује исту проблематику Николић представља могуће начине за идентификовање неологизама у оригиналним и преведеним текстовима на корпусу од шест романа. Закључак до којег долази јесте да не постоји униформан начин упућивања на неологизме, као и да се преводиоци служе посебним техникама приликом превођења (Nikolić, 2020a).

Што се тиче радова из области лексикографије, споменућемо три. Тривић представља важност једнојезичних речника српског језика у контрастивним фразеолошким истраживањима српског и шпанског. Према речима ауторке, ови речници су у највећем броју случајева или примарна, или полазна грађа за контрастивну анализу, па стога систематизује информације које они нуде (Тривић, 2018).

Пејовић у свом раду таксономски представља двојезичне и вишејезичне речнике српског, хрватског и шпанског језика објављене на територији Србије и Хрватске (Pејоvić, 2020a).

Још један рад ауторке Пејовић из ове области нуди преглед речника који садрже шпански и српски језик, а објављени су на територији бивше Југославије и Републике Србије закључно са 2019. годином. Речници су подељени на три категорије: 1) двојезични речници који укључују шпански и српскохрватски је- 
зик; 2) двојезични шпанско-српски / српско-шпански речници и 3) вишејезични речници који укључују шпански и српски језик (Pejović, 2020b). Како закључује Пејовић, лексикографија на нашим просторима треба да понуди још много тога што је остало недоречено $и$ што може да се доради.

Из приложеног се закључује да су у претходној деценији фразеолошке јединице заузеле највише место на лествици констрастивних истраживања у области лексикологије, и шире, у области фразеологије. Приступано им је са различитих становишта, а компарација је поред српског и шпанског у неким случајевима укључила и трећи језик. Резултати до којих су аутори дошли показују висок степен сличности у погледу културолошких особености Србије и Шпаније. У овој области највише се истичу радови ауторки Анђелке Пејовић $и$ Анете Тривић.

\section{4. Контрастивна истраживања српског и шпанског језика из обла- сти традуктологије}

Рулић и Пејовић (2014) се у свом раду баве језичким јединицама које захтевају велику посвећеност и способност преводиоца да их савлада, а ради се о културемама, са акцентом на антропонимима и топонимима у познатим књижевним делима за децу и младе. Због општепознате чињенице да превођење културема представља један од највећих изазова за преводиоце зато што је повезано са културним својствима једног народа која не одликују други, ауторке су увиделе потребу да представе и објасне стратегије којима преводиоци најчешће прибегавају. Закључци до којих долазе јесте да не постоји универзално правило за превођење културема, већ да их постоји много и да често и нису правила већ умешност да се пронађе одговарајуће решење за одређени контекст.

Рулић и Николић (2018) се баве превођењем са шпанског на српски у оквиру стручног језика туристичког сектора. Циљ њиховог истраживања јесте да укажу на технике којима би било омогућено лакше превођење лексике условљене друштвеним променама.

Борхесова проза због своје специфичности пружа могућност за различите приступе у истраживању. Тако се Тривић (2019) бави традуктолошком анализом Борхесовог наратива и поставља рад на два плана. На првом испитује симболе и веома специфичан стил Борхесове прозе, са посебним освртом на симбол лавиринта који назива ауторовом опсесијом. Други део анализе посвећен је појединостима везаним за сам превод. Тривић запажа да је преводилац Константиновић успео да пренесе у српски језик комплексност Борхесовог стила прилагођавајући га лингвистичким особеностима српског језичког система.

Исте године, Тривић и Николић (2019) упоређују неколико превода Борхесове кратке приче Deutsches Requiem на српски језик. Језички елементи се испитују на фонетско-фонолошком, морфолошком, синтаксичком и лексичком нивоу, а уочене су и различите технике којима су се преводиоци служили.

У оквиру зборника Estudios hispánicos en la cultura y ciencia Serbia (2016) неколико радова обрађује традуктолошку проблематику. Донић (2016) пред- 
ставља историјски и друштвени контекст превода хиспаноамеричке поезије на српски језик. У овом раду су приказана преводилачка достигнућа преведене поезије од почетка XX до прве деценије XXI века.

Бајић (20156) приказује на чему се заснива превођење правних текстова са шпанског језика на српски и обрнуто. Ауторка овој проблематици приступа због тога што се на матичним студијама хиспанистике у нашој земљи не обрађује језик правне струке. Након представљања правно-преводилачког образовања и правног система, Бајић указује на најважније особине шпанског правног језика, осврћући се на кључне морфосинтаксичке и семантичко-лексичке проблеме са којима се преводиоци могу сусрести.

У оквирима транслингвистике Лазић (2016) објашњава процес превођења са српског на шпански на примеру филма Црна мачка, бели мачор Емира Кустурице. Ауторку посебно занимају социјални, културни и иронични аспекти у самој текстуалности поменутог филмског превода.

Ковачевић Петровић (2016) прави паралелу између књижевних и специјализованих превода заснованих на писменом и усменом дискурсу са преводилачког становишта.

У област традуктолошких студија укључујемо и дисертацију ауторке Андријане Ђордан под називом Језичка политика и терминологија у професионалним доменима језичке употребе у стандардном шпанском и српском језику (2016). Тема истраживања је однос језичке политике и терминологије у области менаџмента Србије и Шпаније. Циљ је сређивање и стандардизација терминологије струке.

Када говоримо о традуктологији, можемо закључити да су се преводиоци у претходној деценији у својим научним радовима осим разматрања о преводилачким техникама углавном бавили компаративном анализом одређених језичких јединица или упоређивањем различитих превода са једног на други језик, чешће са шпанског на српски. На основу приложених радова примећујемо да све више расте интересовање хиспаниста за компаративна истраживања у овој области.

\section{5. Контрастивна истраживања српског и шпанског језика из обла- сти прагматике}

Валожић (2019) пореди рекламе за пиво у Србији и Шпанији и пружа увид у различите друштвене околности. Циљ рада је скретање пажње на културну и друштвену различитост постојећу у анализираним рекламама. Поред тога, овај рад се може сматрати корисним и у области методичких истраживања због тога што се изучава дидактичка сврха контрастирања реклама на часовима шпанског као страног језика.

Рајић (2013) испитује семантичко-функционална својства речце дакле (luego / con que) и њених еквивалената на шпанском језику. Резултат истраживања показује да ова речца има двојаку употребу јер остварује два типа везе, односно објашњене / одбитак и узрок / ефекат. 
Бељић (2015) у оквиру социолингвистичког истраживања анализира и упоређује дијалекте југа Шпаније и Србије. Циљ рада је испитивање положаја ових дијалеката и њихов однос са стандардним језицима, шпанским и српским. Ауторку такође занима зашто настају предрасуде о андалузијском наречју и говору јужне Србије.

Бајић је велики део свог научног опуса посветила проучавању дискурзивних маркера. У једном од радова указује на значај контрааргументативних дискурзивних партикула у шпанском и српском језику приликом учења шпанског као страног језика (Вајіс́ 2014).

Касније, Бајић упоређује српски и шпански дискурс на основу различитих глаголских система ова два језика. У фокусу рада је категорија модалности у шпанском и српском, као и језичка средства којима се исказује одговарајућа намера говорника (Бајић, 2015а).

У наредном истраживању Бајић сагледава семантичку проблематику дискурзивних маркера и указује на недовољну истраженост контрастивне српскошпанске анализе адитивних конектора. Ово запажање отвара могућности за детаљнија испитивања ових језичких јединица. Како ауторка истиче, радови који се баве семантичком анализом могу послужити како студентима и професорима, тако и преводиоцима (Bajić, 2016а).

Исте године Бајић је одбранила докторску дисертацију под називом Реформулативни дискурсни маркери у савременом шпанском и српском језику у којој је пажња посвећена дискурзивним маркерима којима се делови текста повезују у кохерентну целину (Bajić, 2016b).

Чланак који се заснива на делу анализе из тезе Драгане Бајић представља ауторкино истраживање у коме се објашњавају реформулативни маркери који се користе приликом потребе за преформулацијом одређених дискурсних делова (Bajić, 2019).

На примерима из корпуса у оквиру учења шпанског као страног језика Бајић (2017) настоји да објасни карактеристике реформулативног дискурсног маркера о sea, експликативног значења, а еквиваленти у српском језику су му то јест, односно, наиме, (то) значи, ито ће рећи, или.

Даље, Бајић (2018) представља сличности и разлике дискурзивних маркера удаљености (у сваком случају, у најбољем случају, у најмаюу руку, на сваки начин) у шпанском и у српском језику. Класификација ових маркера је извршена на основу прагматичких критеријума шпанских аутора који се више од србиста баве овом проблематиком. Утврђено је да овај тип дискурзивних маркера прави проблеме и студентима који уче шпански као страни језик и преводиоцима.

Маријана Алексић је у једном раду испитивала језичко кодирање евиденцијалности на корпусу чланака из српских и шпанских новина. На основу анализе евиденцијалних маркера који су неизоставни елементи журналистичког дискурса ауторка упоређује српски и шпански језик и долази до закључка да се евиденцијалност најчешће исказује кроз употребу управног и неуправног говора (Алексић, 2019). 
Наредне године Алексић (2020) је одбранила докторску дисертацију под називом Облици индикатива и субјунктива у шпанском језику и юихови еквиваленти у српском: семантичко-прагматичка анализа и дидактичке импликације. Ауторка је на основу спроведеног истраживања показала да категорија начина представља велики проблем не само приликим учења шпанског на почетним нивоима, већ и међу испитаницима који имају висок ниво знања језика, што углавном упућује на недостатак прагматичке компетенције.

Рајић (2014а) упоређује дискурзивне маркере последичних реченица у српском и шпанском језику из угла теорије релеванције, теорије аргументације и Грајсових конверзационих начела. Циљ рада је да се дефинише њихово значење и функција и да се укаже на могуће сличности и разлике у употреби у оба језика.

Када је реч о контрастивним истраживањима из области прагматике, закључујемо да су највише истраживани функција и значај дискурзивних маркера, елемената чија је улога да повежу текст у смислену целину која преноси одређену намеру. Највећи допринос овој области пружиле су ауторке Драгана Бајић и Јелена Рајић.

\section{6. Закључне напомене}

У овом раду смо представили објављене радове контрастивних истраживања српског и шпанског језика у периоду између 2011. и 2020. године. Радови су распоређени према областима којима припадају како би се обезбедио прегледан увид у различите лингвистичке категорије и олакшала претрага истих. Обрађено је 90 научних радова, 6 докторских дисертација и 2 научне монографије из области граматике, лексикологије, традуктологије и прагматике. У ово истраживање нисмо укључили радове српских хиспаниста који су објављени у иностранству, већ смо се усредсредили на радове објављене на територији Србије.

На основу спроведене анализе закључујемо да у овој деценији имамо далеко већи број истраживања (90 научних радова) него у претходној (16 научних радова ${ }^{1}$. Такође запажамо да је интересовање за упоредно изучавање хиспанистике и србистике драстично порасло, пре свега у области лексиколошких и фразеолошких истраживања.

Извршено истраживање је показало велики утицај еминентних стручњака на младе истраживаче из готово свих анализираних области. О томе сведочи 6 одбрањених докторксих дисертација.

Констататујемо да је и даље приметно веће интересовање аутора за контрастивна изучавања два језика, конкретно српског и шпанског, међутим, има и радова у којима је уведен трећи језик (хебрејско-шпански, енглески или руски). Уколико упоредимо ова истраживања, може се увидети да историја и друштвени контексти у великој мери утичу на начин перцепције света око нас што се

1 Изузети су радови који припадају пољу соцолингвистике. 
такође одражава на језичка средства. То се највише уочава кроз анализирање фразеологизама, а резултати до којих се долази потврђују сличност између различитих култура, првенствено словенских, тј. сродних.

Уколико упоредимо радове из области фонетике и фонологије из ове деценије са претходном можемо увидети да су они контрастивног карактера све више усмерени ка ревидирању правила транскрибовања шпанских речи. Ова изучавања су уско повезана са традуктолошким студијама и преводилачком делатношћу, у којима се најефективније могу применити.

На основу свега реченог и представљеног у овом раду можемо указати на огроман успон контрастивних истраживања у области филолошких наука у нашој земљи. Тај значај се огледа у чињеници да резултати до којих се долази у једној лингвистичкој области у великој мери могу послужити истраживачима у некој другој. Осим тога, многа истраживања могу бити од користи наставницима шпанског као страног језика. Могу им послужити као комплементарни материјал или инспирација за креирање активности за једноставније усвајање оних језичких феномена који не постоје у српском, као што су, на пример, одређени и неодређени члан или субјунктив у шпанском језику.

Оно што је другачије у односу на радове написане у периоду пре 2011. године јесте степен интересовања за контрастивна истраживања српског и шпанској језика у анализираним областима. Раније је већи акценат стављен на социолингвистичка истраживања и језичко раслојавање, док је у последњој деценији интересовање аутора највише окренуто лексиколошким и фразеолошким истраживањима.

Када говоримо о областима које нуде још простора за компаративне студије, можемо рећи да су све испитане области отворене за проучавања у којима би се контрастирали језици, два или више. Такве анализе би пре свега олакшале посао преводиоцима, али и отклониле сумње везане за културолошке аспекте. У складу са тим, и културеме спадају у потенцијалну категорију за изучавање, а поређење више језика/култура пружило би бољи увид у сличности и разлике међу њима. Такође, сматрамо да традуктологија пружа могућности за испитивање синтаксичких особености и лексичких феномена, попут неологизама $и$ окационализама, којима у претходном периоду није детаљније приступано.

Надамо да ће овај рад олакшати посао истраживачима хиспанистима и да ће наставити овом узлазном путањом, као и да ће наредни радови указати на неке нове проблеме, као и на адекватна решења за њих. 


\section{Литература}

Алексић, М. (2019). Језичко кодирање евиденцијалности у српском и шпанском новинском дискурсу. Филолог, X, 371-392.

[Aleksić, M. (2019). Jezičko kodiranje evidencijalnosti u srpskom i španskom novinskom diskursu. Filolog, X, 371-392]

Алексић, М. (2020). Облици индикатива и субјунктива у шпанском језику и њихови еквиваленти у српском: семантичко-прагматичка анализа и дидактичке импликације. Београд: Филолошки факултет .

[Aleksić, M. (2020). Oblici indikativa i subjunktiva u španskom jeziku i njihovi ekvivalenti u srpskom: semantičko-pragmatička analiza i didaktičke implikacije. Beograd: Filološki fakultet]

Бајић, Д. (2015а). Модалност дискурса и у дискурсу. У Б. Димитријевић, Б. Мишић Илић и В. Лопичић (ур.), Језик, књижевност, дискурс: Језичка истраживањьа (стр. 449-462). Ниш: Филозофски факултет .

[Bajić, D. (2015a). Modalnost diskursa i u diskursu. U B. Dimitrijević, B. Mišić Ilić i V. Lopičić (ur.), Jezik, književnost, diskurs: Jezička istraživanja (pp. 449-462). Niš: Filozofski fakultet]

Бајић, Д. (20156). Превођење правних текстова са шпанског и на шпански. Зборник радова 'Страни језик струке: прошлост, садашюост, будућност' (стр. 85-93). Београд, ФОН.

[Bajić, D. (2015b). Prevođenje pravnih tekstova sa španskog i na španski. Zbornik radova 'Strani jezik struke: prošlost, sadašnjost, budućnost' (pp. 85-93). Beograd: FON]

Бељић, И., Ковачевић Петровић Б., Донић Ж. (2019). Правописна норма и традиција у транскрипцији шпанских графема сh и z на српски језик. У М. Ковачевић (ур.), Нови прилози српском правопису, Зборник радова са научног скупа „Актуелна питањь српског правописа“ (стр. 217-234). Нови Сад: Матица српска/Вишеград: Андрићев институт.

[Beljić, I., Kovačević Petrović B., Donić Ž. (2019). Pravopisna norma i tradicija u transkripciji španskih grafema ch i z na srpski jezik. U M. Kovačević (ur.), Novi prilozi srpskom pravopisu, Zbornik radova sa naučnog skupa „Aktuelna pitanja srpskog pravopisa“ (pp. 217-234). Novi Sad: Matica srpska/Višegrad: Andrićev institut]

Георгијев, И. (2014). Темпоралност и аспектуалност у српском и шпанском језику. Речи, 6(7), 56-67.

[Georgijev, I. (2014). Temporalnost i aspektualnost u srpskom i španskom jeziku. Reči, 6(7), 56-67]

Георгијев, И. (2015). Табуи и еуфемизми као пример когнитивног културног модела: смрт у српском и шпанском језику. Наслеђе, 30, 221-230.

[Georgijev, I. (2015). Tabui i eufemizmi kao primer kognitivnog kulturnog modela: smrt u srpskom i španskom jeziku. Nasleđe, 30, 221-230]

Георгијев, И. (2017). Љубав и новац у српским и шпанским паремијама. Живи језиии: часопис за стране језике и кюижевности, 37, 91-109.

[Georgijev, I. (2017). Ljubav i novac u srpskim i španskim paremijama. Živi jezici: časopis za strane jezike i književnosti, 37, 91-109] 
Георгијев, И. (2018а). Когнитивни културни модели: ,ьубав у српским и шпанским паремијама. Београд: Филолошки факултет.

[Georgijev, I. (2018a). Kognitivni kulturni modeli:, ljubav' u srpskim i španskim paremijama. Beograd: Filološki fakultet]

Голяк, С. В., Пейович, А. (2018). Символика вкуса в русской, сербской и испанской лексике и фразеологии. В Ж. Кастельви, А. Зайнульдинов, И. Гарсия и М. Руис-Соррилья / J. Castellví, A. Zainouldinov, I. Garcia у M. Ruiz-Zorrilla (ред.), Актуальные проблемы и перспективы русистики / Current Trends and Future Perspectives in Russian Studies (pp. 1093-1105). Barcelona: Trialba Ediciones.

[Golyak. C. V., Peyovich, A. (2018). Simvolika vkusa v russkoy, serbskoy i ispanskoy leksike i frazeologii. U Zh. Kastelvi, A. Zaynuldinov, I. Garsiya i M. Ruis-Sorrilia (Red.), Aktualnyye problemy i perspektivy rusistiki/Current Trends and Future Perspectives in Russian Studies (pp. 1093-1105). Barcelona: Trialba Ediciones]

Ђордан, А. (2016). Језичка политика и терминологија у професионалним доменима језичке употребе у стандардном шпанском и српском језику (необјављена докторска дисертација). Филолошки факултет у Београду.

[Đordan, A. (2016). Jezička politika i terminologija u profesionalnim domenima jezičke upotrebe $u$ standardnom španskom $i$ srpskom jeziku (neobjavljena doktorska disertacija). Filološki fakultet u Beogradu]

Ђуричић, М. (2014). Контрастивна анализа простог футура у шпанском и футура у српском језику. Речи, 6(7), 68-79.

[Đuričić, M. (2014). Kontrastivna analiza prostog futura u španskom i futura u srpskom jeziku. Reči, 6(7), 68-79]

Ђуричић, М., Георгијев И. (2015). Преглед истраживања из контрастивне анализе шпанског и српског језика. Липар, часопис за књижевност, језик, уметност и културу, XVI(58), 211-220.

[Đuričić, M., Georgijev I. (2015). Pregled istraživanja iz kontrastivne analize španskog i srpskog jezika. Lipar, časopis za književnost, jezik, umetnost i kulturu, XVI(58), 211220]

Зечевић-Крнета, Г. (2017). Употреба одређеног члана у шианском као страном језику на основу анализе грешака код говорника српског језика (необјављена докторска дисертација). Филолошко-уметнички факултет, Универзитет у Крагујевцу.

[Zečević-Krneta, G. (2017). Upotreba određenog člana u španskom kao stranom jeziku na osnovu analize grešaka kod govornika srpskog jezika (neobjavljena doktorska disertacija). Filološko-umetnički fakultet, Univerzitet u Kragujevcu]

Кузмановић-Јовановић, А. (2012). Безвучни фрикатив /h/ у шпанском и српском језику - у прилог универзалној теорији језичке промене. Анали Филолошког факултета, 24(1), 155-165.

[Kuzmanović-Jovanović, A. (2012). Bezvučni frikativ/h/ u španskom i srpskom jeziku - u prilog univerzalnoj teoriji jezičke promene. Anali Filološkog fakulteta, 24(1), 155-165]

Николић, И. (20206). Неологизми: одређење термина и преглед истраживања у шпанској и српској лингвистици. En V. Karanović у A. Pejović (Eds.), El legado 
hispánico en el mundo multicultural. Volumen monográfico en homenaje al prof. Dalibor Soldatić (pp. 435-455). Belgrado: Facultad de Filología.

[Nikolić, I. (2020b). Neologizmi: određenje termina i pregled istraživanja u španskoj i srpskoj lingvistici. En V. Karanović y A. Pejović (Eds.), El legado hispánico en el mundo multicultural. Volumen monográfico en homenaje al prof. Dalibor Soldatić (pp. 435-455). Belgrado: Facultad de Filología]

Николић, И., Шарчевић, А. (2012). Концептуалне метафоре у српском, енглеском и шпанском језику: локализација унутар универзалног система. У М. Ковачевић (ур.), Савремена проучавања језика и кюижевности, Зборник радова са III научног скупа младих филолога Србије, књ. 1 (стр. 297-307). Крагујевац: Филолошкоуметнички факултет.

[Nikolić, I., Šarčević, A. (2012). Konceptualne metafore u srpskom, engleskom i španskom jeziku: lokalizacija unutar univerzalnog sistema. U M. Kovačević (ur.), Savremena proučavanja jezika i književnosti, Zbornik radova sa III naučnog skupa mladih filologa Srbije, knj. 1 (pp. 297-307). Kragujevac: Filološko-umetnički fakultet]

Николић, И., Шарчевић, А., Тривић, А. (2012). Когнитивна теорија метафоре: културолошке сличности и разлике у концептима хране и пића у шпанском, енглеском и српском језику. En A. Pejović, M. Sekulić y V. Karanović (Eds.), Comida y bebida en la lengua española, cultura y literaturas hispánicas (pp. 209-227). Kragujevac: Facultad de Filología y Artes.

[Nikolić, I., Šarčević, A., Trivić, A. (2012). Kognitivna teorija metafore: kulturološke sličnosti i razlike u konceptima hrane i pića u španskom, engleskom i srpskom jeziku. En A. Pejović, M. Sekulić y V. Karanović (Eds.), Comida y bebida en la lengua española, cultura y literaturas hispánicas (pp. 209-227). Kragujevac: Facultad de Filología y Artes]

Пејовић, А. (2011a). Додатна запажања о поредбеним фразеологизмима у српском и шпанском језику. У М. Ковачевић (ур.), Кюижевни (стандардни) језик и језик књижевности (стр. 185-191). Крагујевац: Филолошко-уметнички факултет.

[Pejović, A. (2011a). Dodatna zapažanja o poredbenim frazeologizmima u srpskom i španskom jeziku. U M. Kovačević (ur.), Književni (standardni) jezik i jezik književnosti (pp. 185-191). Kragujevac: Filološko-umetnički fakultet]

Пејовић, А. (2013а). Конституисање етичких вредности кроз паремије на примеру српског и шпанског језика. У Б. Мишић-Илић и В. Лопичић (ур.), Језик, књижевност, вредности: језичка истраживаюа (зборник радова) (стр. 113-124). Ниш: Филозофски факултет.

[Pejović, A. (2013a). Konstituisanje etičkih vrednosti kroz paremije na primeru srpskog i španskog jezika. U B. Mišić-Ilić i V. Lopičić (ur.), Jezik, književnost, vrednosti: jezička istraživanja (zbornik radova) (pp. 113-124). Niš: Filozofski fakultet]

Пејовић, А. (20136). О еквиваленцији и лажним пријатељима у шпанској и српској фразеологији. Српски језик, 18, 401-414.

[Pejović, A. (2013b). O ekvivalenciji i lažnim prijateljima u španskoj i srpskoj frazeologiji. Srpski jezik, 18, 401-414] 
Пејовић, А. (2013г). О симболици боја у фразеолошком систему српског и шпанског језика: црно на бело. У М. Ковачевић (ур.), Традиција и иновације у савременом српском језику (стр. 399-409). Крагујевац: Филолошко-уметнички факултет.

[Pejović, A. (2013g). O simbolici boja u frazeološkom sistemu srpskog i španskog jezika: crno na belo. U M. Kovačević (ur.), Tradicija i inovacije u savremenom srpskom jeziku (pp. 399-409). Kragujevac: Filološko-umetnički fakultet]

Пејовић, А. (2014а). Вишезначност у фразеологији (на примеру српског и шпанског језика). У М. Ковачевић (ур.), Вишезначност у језику (стр. 319-331). Крагујевац: Филолошко-уметнички факултет.

[Pejović, A. (2014a). Višeznačnost u frazeologiji (na primeru srpskog i španskog jezika). U M. Kovačević (ur.), Višeznačnost u jeziku (pp. 319-331). Kragujevac: Filološkoumetnički fakultet]

Пејовић, А. (2014в). Како видимо једни друге: називи националности и 8 професија у фразеологији српског и шпанског језика. У С. Гудурић и М. Стефановић (ур.), Језици и културе у времену и простору III/1 (стр. 77-87). Нови Сад: Филозофски факултет.

[Pejović, A. (2014v). Kako vidimo jedni druge: nazivi nacionalnosti i 8 profesija u frazeologiji srpskog i španskog jezika. U S. Gudurić i M. Stefanović (ur.), Jezici i kulture u vremenu i prostoru III/1 (pp. 77-87). Novi Sad: Filozofski fakultet]

Пејовић, А. (2014д). Паремије као део етнолингвистичког наслеђа. Гласник Етнографског института САНУ, 62(2), 201-214.

[Pejović, A. (2014d). Paremije kao deo etnolingvističkog nasleđa. Glasnik Etnografskog instituta SANU, 62(2), 201-214]

Пејовић, А. (2015а). Контрастивна фразеологија шпанског и српског језика. Крагујевац: Филолошко-уметнички факултет.

[Pejović, A. (2015a). Kontrastivna frazeologija španskog i srpskog jezika. Kragujevac: Filološko-umetnički fakultet]

Пејовић, А. (20156). Паремиолошки континуум од Вука до данас. У М. Ковачевић и Ј. Петковић (ур.), Српски језик - од Вука до данас (стр. 193-202). Крагујевац: Филолошко-уметнички факултет.

[Pejović, A. (2015b). Paremiološki kontinuum od Vuka do danas. U M. Kovačević i J. Petković (ur.), Srpski jezik - od Vuka do danas (pp. 193-202). Kragujevac: Filološkoumetnički fakultet]

Пејовић, А. (20166). 'Крв’ као фразеолошка компонента у српском и шпанском језику. У М. Ковачевић и Ј. Петковић (ур.), Језик, кюижевност, уметност (стр. 357-367). Крагујевац: Филолошко-уметнички факултет.

[Pejović, A. (2016b). 'Krv' kao frazeološka komponenta u srpskom i španskom jeziku. U M. Kovačević i J. Petković (ur.), Jezik, književnost, umetnost (pp. 357-367). Kragujevac: Filološko-umetnički fakultet]

Пејовић, А. (2016в). Културеме унутар фразема и фраземи као културеме. Српски језик, XXI, 133-144.

[Pejović, A. (2016v). Kultureme unutar frazema i frazemi kao kultureme. Srpski jezik, XXI, 133-144] 
Пејовић, А. (20186). О динамичности и екстензивној експресивности паремија (на примеру шпанског и српског језика). У С. Гудурић и Б. Радић-Бојанић (ур.), Језици и културе у времену и простору, VII/1 (стр. 195-206). Нови Сад: Филозофски факултет.

[Pejović, A. (2018b). O dinamičnosti i ekstenzivnoj ekspresivnosti paremija (na primeru španskog i srpskog jezika). U S. Gudurić i B. Radić-Bojanić (ur.), Jezici i kulture u vremenu i prostoru, VII/1 (pp. 195-206). Novi Sad: Filozofski fakultet]

Пејовић, А. (2018в). О значењу и употреби имперфекта у у шпанском језику у односу на српски. У Ј. Петковић и В. Поломац (ур.), Српски језик: статус, систем, употреба. Зборник радова у част проф. Милошу Ковачевићу (стр. 733-756). Крагујевац: Филолошко-уметнички факултет.

[Pejović, A. (2018v). O značenju i upotrebi imperfekta u u španskom jeziku u odnosu na srpski. U J. Petković i V. Polomac (ur.), Srpski jezik: status, sistem, upotreba. Zbornik radova u čast prof. Milošu Kovačeviću (pp. 733-756). Kragujevac: Filološkoumetnički fakultet]

Петровић, М. (2014). Глаголске перифразе са герундом у шпанском и њихови преводни еквиваленти у српском језику. У М. Ковачевић и Ј. Петковић (ур.), Савремена проучавања језика и књижевности, Зборник са V научног скупа младих филолога Cрбије, књ. 1 (стр. 261-268). Крагујевац: Филолошко-уметнички факултет.

[Petrović, M. (2014). Glagolske perifraze sa gerundom u španskom i njihovi prevodni ekvivalenti u srpskom jeziku. U M. Kovačević i J. Petković, Savremena proučavanja jezika i književnosti, Zbornik sa V naučnog skupa mladih filologa Srbije, knj. 1 (pp. 261-268). Kragujevac: Filološko-umetnički fakultet]

Петровић, М., Тулимировић, Б. (2014). Придевски пароними у српском и њихови преводни еквиваленти у шпанском језику. Наслеђе, 28, 25-38.

[Petrović, M., Tulimirović, B. (2014). Pridevski paronimi u srpskom i njihovi prevodni ekvivalenti u španskom jeziku. Nasleđe, 28, 25-38]

Рајић, J. (2012). Евиденцијалне стратегије у српском и шпанском језику - језичко кодирање извора информације у српском и шпанском језику. Српски језик студије српске и словенске, 17, 463-472.

[Rajić, J. (2012). Evidencijalne strategije u srpskom i španskom jeziku - jezičko kodiranje izvora informacije u srpskom i španskom jeziku. Srpski jezik - studije srpske i slovenske, 17, 463-472]

Рајић, J. (2013). Семантика и прагматика дискурсне партикуле дакле и њени преводни еквиваленти у шпанском језику. Српски језик, 18, 497-512.

[Rajić, J. (2013). Semantika i pragmatika diskursne partikule dakle i njeni prevodni ekvivalenti u španskom jeziku. Srpski jezik, 18, 497-512]

Рајић, J. (20146). Хиспанизми и лузизми у савременом српском језику. Анали Филолошког факултета, XXVI(2), 21-38.

[Rajić, J. (2014b). Hispanizmi i luzizmi u savremenom srpskom jeziku. Anali Filološkog fakulteta, XXVI(2), 21-38]

Рулић, Д., Николић, И. (2018). Идентификација проблема у стручним текстовима из туристичког сектора. У А. Вујовић, С. Шипрагић Ђокић и М. Папрић (ур.), Стра- 
ни језик струке и професионални идентитет (стр. 507-532). Београд: Друштво за стране језике и књижевности Србије.

[Rulić, D., Nikolić, I. (2018). Identifikacija problema u stručnim tekstovima iz turističkog sektora. U A. Vujović, S. Šipragić Đokić i M. Paprić (ur.), Strani jezik struke i profesionalni identitet (pp. 507-532). Beograd: Društvo za strane jezike i književnosti Srbije]

Рулић, Д., Пејовић, А. (2014). Превођење властитих имена у књижевности за децу и младе. Лunap, 54, 43-55.

[Rulić, D., Pejović, A. (2014). Prevođenje vlastitih imena u književnosti za decu i mlade. Lipar, 54, 43-55]

Танасијевић, А. (2017). Глаголи ser и estar у шпанском језику и њихови еквиваленти у српском. Лunap, 64, 121-144.

[Tanasijević, A. (2017). Glagoli ser i estar u španskom jeziku i njihovi ekvivalenti u srpskom. Lipar, 64, 121-144]

Танасијевић, А. (2019). Семантичка анализа фразеолошких јединица са компонентом бог у шпанском и српском језику. У М. Ковачевић и Ј. Петковић (ур.), Савремена проучавања језика и књижевности, Зборник радова са X научног скупа младих филолога Србије (стр. 129-139). Крагујевац: Филолошко-уметнички факултет.

[Tanasijević, A. (2019). Semantička analiza frazeoloških jedinica sa komponentom bog u španskom i srpskom jeziku. U M. Kovačević i J. Petković (ur.), Savremena proučavanja jezika i književnosti, Zbornik radova sa X naučnog skupa mladih filologa Srbije (pp. 129-139). Kragujevac: Filološko-umetnički fakultet]

Тривић, А. (20136). Семантичка анализа идиоматских израза с компонентом 'глава' у савременом српском и шпанском језику. У М. Ковачевић (ур.), Традиција и иновације у савременом српском језику (стр. 411-420). Крагујевац: Филолошкоуметнички факултет.

[Trivić, A. (2013b). Semantička analiza idiomatskih izraza s komponentom 'glava' u savremenom srpskom i španskom jeziku. U M. Kovačević (ur.), Tradicija i inovacije u savremenom srpskom jeziku (pp. 411-420). Kragujevac: Filološko-umetnički fakultet]

Тривић, А. (20136). Нека теоријска питања из шпанске и српске фразеологије: одређење фразеолошке јединице. У Ј. Вучо и В. Половина (ур.), Савремени токови у ^ингвистичким истраживањима, књ. 2 (стр. 41-56). Београд: Филолошки факултет.

[Trivić, A. (2013b). Neka teorijska pitanja iz španske i srpske frazeologije: određenje frazeološke jedinice. U J. Vučo i V. Polovina (ur.), Savremeni tokovi u lingvističkim istraživanjima, knj. 2 (pp. 41-56). Beograd: Filološki fakultet]

Тривић, А. (2015а). Лексичко-семантичка анализа соматизама у фразеологији савременог шианског и српског језика: контрастивни приступ (необјављена докторска дисертација). Филолошко-уметнички факултет, Универзитет у Крагујевцу.

[Trivić, A. (2015a). Leksičko-semantička analiza somatizama u frazeologiji savremenog španskog i srpskog jezika: kontrastivni pristup (neobjavljena doktorska disertacija). Filološko-umetnički fakultet, Univerzitet u Kragujevcu] 
Тривић, А. (20156). О преводној еквиваленцији на примеру мимичког фразеологизма отоворити очи. Липар, 55, 63-80.

[Trivić, A. (2015b). O prevodnoj ekvivalenciji na primeru mimičkog frazeologizma otovoriti oči. Lipar, 55, 63-80]

Тривић, А. (2015). Фраземи с компоненатама рука и тапо као карактеризатори човека у српском и шпанском језику. Зборник Матище српске за филологију и мингвистику, LVIII(2), 191-204.

[Trivić, A. (2015). Frazemi s komponenatama ruka i mano kao karakterizatori čoveka u srpskom i španskom jeziku. Zbornik Matice srpske za filologiju i lingvistiku, LVIII(2), 191-204]

Тривић, А. (2016а). Културолошка условљеност соматске фразеологије српског и шпанског језика. У А. Вранеш и Љ. Марковић (ур.), Филологија културе, књ. 1 (стр. 93-111). Београд: Филолошки факултет.

[Trivić, A. (2016a). Kulturološka uslovljenost somatske frazeologije srpskog i španskog jezika. U A. Vraneš i Lj. Marković (ur.), Filologija kulture, knj. 1 (pp. 93-111). Beograd: Filološki fakultet]

Тривић, А. (2016). Семантички параметри идиоматске компарације на примеру шпанског и српског језика. Српски језик, XXI, 203-218.

[Trivić, A. (2016). Semantički parametri idiomatske komparacije na primeru španskog i srpskog jezika. Srpski jezik, XXI, 203-218]

Тривић, А. (2017а). Телесне метафоре с временским значењем у српском и шпанском језику. У Б. Мишић Илић и В. Лопичић (ур.), Језичка истраживања. Језик, књижевност, време (стр. 229-242). Ниш: Филозофски факултет.

[Trivić, A. (2017a). Telesne metafore s vremenskim značenjem u srpskom i španskom jeziku. U B. Mišić Ilić i V. Lopičić (ur.), Jezička istraživanja. Jezik, književnost, vreme (pp. 229-242). Niš: Filozofski fakultet]

Тривић, А. (2017б). Тело, простор, време: метафоричка пресликавања у соматској фразеологији. У С. Гудурић и Б. Радић-Бојанић (ур.), Језици и културе у времену u простору VI (стр. 219-228). Нови Сад: Филозофски факутет.

[Trivić, A. (2017b). Telo, prostor, vreme: metaforička preslikavanja u somatskoj frazeologiji. U S. Gudurić i B. Radić-Bojanić (ur.), Jezici i kulture u vremenu i prostoru VI (pp. 219-228). Novi Sad: Filozofski fakutet]

Тривић, А. (2018). Улога српских речника у контрастивнолингвистичким истраживањима на плану српског и шпанског језика. Научни састанак слависта у Вукове дане, 47(1), 325-334.

[Trivić, A. (2018). Uloga srpskih rečnika u kontrastivnolingvističkim istraživanjima na planu srpskog i španskog jezika. U Naučni sastanak slavista u Vukove dane, 47(1), 325-334]

Тривић, А., Пејовић, А. (2020). Интензификација експресивности у фразеологији српског и шпанског језика. У М. Ковачевић и Ј. Петковић (ур.), Експресивност у српском језику (стр. 351-364). Крагујевац: Филолошко-уметнички факултет.

[Trivić, A., Pejović, A. (2020). Intenzifikacija ekspresivnosti u frazeologiji srpskog i španskog jezika. U M. Kovačević i J. Petković (ur.), Ekspresivnost u srpskom jeziku (pp. 351-364). Kragujevac: Filološko-umetnički fakultet] 
Bajić, D. (2014). Partículas discursivas de significado contraargumentativo en español y en serbio. En A. Kuzmanović Jovanović et al. (Eds.), Estudios hispánicos en el siglo XXI (pp. 319-335). Belgrado: Facultad de Filología.

Bajić, D. (2016b). Marcadores discursivos de reformulación en el español y el serbio acutuales. Beograd: Filološki fakultet.

Bajić, D. (2016a). Conectores aditivos en español y en serbio. En A. Pejović et al. (Eds.), Estudios hispánicos en la cultura y ciencia serbia (pp. 327-337). Kragujevac: Facultad de Filología y Artes.

Bajić, D. (2017). El marcador discursivo o sea y sus equivalentes en serbio. En V. Dickov (Ed.), Identidad, movilidad u perspectivas de los estudios de lengua, literatura $y$ cultura, (pp. 129-158). Belgrado: Facultad de Filología y Pescara, Universidad Gabriele D'Annunzio de Chieti.

Bajić, D. (2018). Marcadores discursivos de distanciameinto, Beoiberística, 2, 57-72.

Bajić, D. (2019). Marcadores reformulativos de reconsideración. En A. Pejović et al. (Eds.), Estudios hispánicos serbios y retos de la contemporaneidad / Actas de la segunda conferencia nacional de hispanistas serbios, Vol. 2 (pp. 73-92). Belgrado: Facultad de Filología.

Beljić, I. (2012). Afrikate u srpskom i španskom: u prilog transkripciji španske afrikate 'ch' srpskom grafemom 'ć'. Anali Filološkog fakulteta, XXIV(2), 59-95.

Beljić, I. (2013). Najčešći problemi u izgovoru i transkripciji imena iz španskog jezika. U J. Vučo i V. Polovina (ur.), Savremeni tokovi u lingvističkim istraživanjima, knj. 2 (pp. 25-40). Beograd: Filološki fakultet.

Beljić, I. (2015). La construcción de las identidades lingüísticas: el caso de la variedad andaluza del español y las modalidades meridionales del serbio. Verba hispanica, XXIII, 87-105.

Beljić, I. (2016). Una aportación al cambio de las reglas de transcripción de nombres propios españoles en serbio. En A. Pejović et al. (Eds.), Estudios hispánicos en la cultura y ciencia serbia (pp. 365-384). Kragujevac: Facultad de Filología y Artes.

Ćirić, M. (2016). Metonimijska konceptualizacija vremena u srpskom i španskom jeziku. Језици и културе у времену и простору, V, 75-84.

Donić, Ž. (2016). Contribución a la bibliografía de traducciones de poesía hispanoamericana en la lengua serbia. En A. Pejović et al. (Eds.), Estudios hispánicos en la cultura y ciencia serbia (pp. 403-411). Kragujevac: Facultad de Filología y Artes.

Filipović, J. (2010). Kontrastivna izučavanja srpskog i španskog jezika. U I. Klajn i P. Piper (ur.), Kontrastivna proučavanja srpskog jezika: pravci i rezultati (pp. 353-375). Beograd: Srpska akademija nauka i umetnosti.

Georgijev, I. (2018b). Metafore o smrti i umiranju u španskom i srpskom jeziku. Godišnjak Filozofskog fakulteta u Novom Sadu, XLIII(2), 181-194.

Georgijev, I. (2019a). Etnolingvistički pristup temi smrti u srpskim i španskim paremijama. U S. Gudurić i B. Radić-Bojanić (ur.), Zbornik radova sa međunarodne konferencije "Jezici i kulture u vremenu i prostoru 8“ (pp. 13-23). Novi Sad: Filozofski fakultet. 
Georgijev, I. (2019b). La muerte como un fenómeno metafísico en las paremias serbias y españolas: Enfoque etnolingüístico. En A. Pejović et al. (Eds.), Estudios hispánicos serbios y retos de la contemporaneidad / Actas de la segunda conferencia nacional de hispanistas serbios, Vol. 2 (pp. 143-156). Belgrado: Facultad de Filología.

Kovačević Petrović, B. (2016). Discurso oral y discurso escrito en la traducción literaria y especializada del español al serbio y del serbio al español. En A. Pejović et al. (Eds.), Estudios hispánicos en la cultura y ciencia serbia (pp. 427-440). Kragujevac: Facultad de Filología y Artes.

Lazić, J. (2016). La traducción como una forma de transformación de la lengua. En A. Pejović et al. (Eds.), Estudios hispánicos en la cultura y ciencia serbia (pp. 413-425). Kragujevac: Facultad de Filología y Artes.

Marcos Blanco, H. (2019). Análisis contrastivo de la temporalidad y aspectualidad de los sistemas verbales español y serbio. En A. Pejović et al. (Eds.), Estudios hispánicos serbios y retos de la contemporaneidad / Actas de la segunda conferencia nacional de hispanistas serbios, Vol. 2 (pp. 429-449). Belgrado: Facultad de Filología.

Nikolić, I. (2020a). La representación gráfica de los neologismos españoles traducidos al serbio. Nasleđe, 45, 193-215.

Pejović, A. (2011b). La traducción serbia de las locuciones verbales en dos obras de Miguel Delibes. Paremia, 20, 29-40.

Pejović, A. (2011c). Las comparaciones estereotipadas en la fraseología española y serbia: análisis contrastivo. En A. Pamies, L. Luque-Nadal y J. Pazos Bretaña (Eds.), Multilingual phraseography: Second Language Learning and Translation Applications (pp. 157-166). Baltmannsweiler: Schneider Verlag.

Pejović, A. (2012). Locuciones con el componente gastronómico en español y en serbio. En A. Pejović, M. Sekulić y V. Karanović (Eds.), Comida y bebida en la lengua española, cultura y literaturas hispánicas (pp. 157-171). Kragujevac: Facultad de Filología y Artes.

Pejović, A. (2013c). La expresión fraseológica de los valores éticos y estéticos. Colindancias, 4, 265-273.

Pejović, A. (2014c). El simbolismo de los colores en español y en serbio a través del prisma de la fraseología. En Z. Bułat Silva, M. Głowicka y J. Wesoła (Eds.), Variación, contraste, circulación. Perspectivas lingüísticas en el hispanismo actual (pp. 137145). Wroclaw: Wydawnictwo Uniwersytetu Wroclawskiego.

Pejović, A. (2014d). Los valores estéticos a través del prisma de la fraseología: casos del español y del serbio. En J. Sevilla Muñoz (Ed.), Fraseología y léxico: un enfoque contrastivo (pp. 79-89). Lugo: Axac.

Pejović, A. (2016a). Análisis semántico-cognitivo de locuciones españolas con los componentes ‘corazón’ y ‘alma’. En A. Pejović et al. (Eds.), Estudios hispánicos en la cultura y ciencia serbia (pp. 223-233). Kragujevac: Facultad de Filología y Artes. Pejović, A. (2018a). Las relaciones familiares en el refranero español, judeoespañol y serbio. En D. M. Bunis, I. Vučina Simović y C. Deppner (Eds.), Caminos de leche y miel: Jubilee Volume in Honor of Michael Studemund-Halévy. Volume II - Language and Literature (pp. 424-443). Barcelona: Tirocinio. 
Pejović, A. (2019). El campo fraseosemántico ‘sabor' en serbio y en español. En A. Pejović et al. (Eds.), Estudios hispánicos serbios y retos de la contemporaneidad / Actas de la segunda conferencia nacional de hispanistas serbios, Vol. 2 (pp. 37-55). Belgrado: Facultad de Filología.

Pejović, A. (2020a). Logros lexicográficos del hispanismo serbio y croata. Revista de Lexicografía, XXVI, 85-103.

Pejović, A. (2020b). O rečnicima koji uključuju španski i srpski jezik. En V. Karanović y A. Pejović (Eds.), El legado hispánico en el mundo multicultural. Volumen monográfico en homenaje al prof. Dalibor Soldatić (pp. 345-371). Belgrado: Facultad de Filología. Pejović, A., Nikolić, I. (2011). La expresión del aspecto perfectivo en los idiomas español y serbio. En C. Sinner, E. Hernández Socas y C. Bahr (Eds.), La expresión de tiempo $y$ espacio $y$ las relaciones espacio-temporales. Nuevas aportaciones de los estudios contrastivos (pp. 131-144). Frankfurt am Main: Peter Lang.

Pejović, A., Trivić, A. (2012). El concepto de 'tiempo' en la fraseología española y Serbia. Verba hispanica, 20(1), 261-277.

Pejović, A., Trivić, A. (2018). Elementos idiosincrásicos en la fraseología serbia y española. En A. Pamies Bertrán, I. M. ${ }^{a}$ Balsas y A. Magdalena (Eds.), Lenguaje figurado y competencia interlingüística. Aspectos teóricos (pp. 101-114). Granada: Editorial Comares.

Petrović Gujaničić, M. (2020). Definición de fórmulas paremiológicas en diccionarios generales y terminológicos en serbio y español. Nasleđe, 45, 83-96.

Petrović, M., Tulimirović, B. (2016). El estatus de las fórmulas rutinarias en los estudios fraseológicos de las lenguas serbia y española. En A. Pejović et al. (Eds.), Estudios hispánicos en la cultura y ciencia serbia (pp. 263-271). Kragujevac: Facultad de Filología y Artes.

Rajić, J. (2014a). Las teorías pragmáticas y el estudio de los marcadores discursivos en español y en serbio. En A. Kuzmanović Jovanović et al. (Eds.), Estudios hispánicos en el siglo XXI (pp. 337-355). Belgrado: Facultad de Filología.

Rajić, J. (2015). Análisis contrastivo de la expresión de la evidencialidad en serbio y español. Verba hispanica, 23(1), 127-148.

Rajić, J. (2016). Adaptación de nombres procedentes del español a la lengua serbia contemporánea. En A. Pejović et al. (Eds.), Estudios hispánicos en la cultura y ciencia serbia (pp. 385-389). Kragujevac: Facultad de Filología y Artes.

Rajić, J. (2019). Las construcciones pseudo-copulativas con verbos de cambio 'hacerse', 'volverse' y 'ponerse' y sus formas equivalentes en serbio. En A. Pejović et al. (Eds.), Estudios hispánicos serbios y retos de la contemporaneidad / Actas de la segunda conferencia nacional de hispanistas serbios, Vol. 2 (pp. 57-71). Belgrado: Facultad de Filología.

Rubinjoni Strugar, V. (2018). El serbio, una muestra para lenguas sin artículo determinado. Belgrado: Studio strugar editores.

Rubinjoni Strugar, V. (2019). Los problemas más pronunciados en el uso del artículo determinado. En A. Pejović et al. (Eds.), Estudios hispánicos serbios y retos de la contemporaneidad / Actas de la segunda conferencia nacional de hispanistas serbios, Vol. 2 (pp. 93-124). Belgrado: Facultad de Filología. 
Trivić, A. (2011). Equivalencias traductológicas de ciertas locuciones del español y serbio contemporáneo. Journal of linguistic and intercultural education JoLIE, IV, 219-238.

Trivić, A. (2013a). Correspondencia recíproca en la fraseología. Análisis contrastivo español-serbio. Colindancias: revista de la Red Regional de Hispanistas de Hungría, Rumanía y Serbia, 4, 69-80.

Trivić, A. (2014). Análisis conceptual y traductológico de las locuciones temporales españolas y serbias. En J. Sevilla Muñoz (Ed.), Fraseología y léxico. Un enfoque contrastivo (pp. 67-77). Lugo: Axac.

Trivić, A. (2019). Sobre la interpretación simbólica y traducción de J. L. Borges en Radivoje Konstantinović. Facta Universitatis. Series: Linguistics and Literature, 17(2), 141-154.

Trivić, A., Lončar, I. (2020). Violación de las normas lingüísticas en las expresiones idiomáticas. Nasleđe, 45, 45-65.

Trivić, A., Nikolić, I. (2019). Análisis lingüístico y traductológico del corpus paralelo de traducciones serbias de Deutsches Requiem de J. L. Borges. En A. Pejović et al. (Eds.), Estudios hispánicos serbios y retos de la contemporaneidad / Actas de la segunda conferencia nacional de hispanistas serbios, Vol. 2 (pp. 407-429). Belgrado: Facultad de Filología.

Valožić, L. (2019). La diversidad cultural y la publicidad: análisis comparativo de anuncios de cerveza de España y Serbia. En A. Pejović et al. (Eds.), Estudios hispánicos serbios $y$ retos de la contemporaneidad / Actas de la segunda conferencia nacional de hispanistas serbios, Vol. 2 (pp. 465-477). Belgrado: Facultad de Filología.

\section{Irena M. Selaković}

Resumen

\section{RESUMEN DE LA INVESTIGACIÓN CONTRASTIVA DE SERBIO Y ESPAÑOL DE LA SEGUNDA DÉCADA DEL SIGLO XXI}

En este artículo presentamos los trabajos publicados sobre el análisis contrastivo de las lenguas serbia y española. Nos basamos en artículos de revisión anteriores sobre este tema (Filipović, 2010, Đuričić y Georgijev, 2015) y los complementamos con nuevos datos sobre artículos publicados en el período de 2011 a 2020. Gracias a los autores serbios del país y región, disponemos de una gran cantidad de los trabajos que presentan similitudes y diferencias entre estos dos idiomas en diferentes niveles lingüísticos. Se analizaron 83 artículos científicos, 6 tesis doctorales y 2 monografías científicas. El objetivo era examinar los intereses en el campo del análisis contrastivo de las lenguas serbia y española y las diferencias y logros en relación con investigaciones anteriores, si las hubiera. Hicimos un esfuerzo por mirar el panorama general y determinar qué áreas lingüísticas deberían ser procesadas y examinadas más a fondo. Por todo lo anterior, el trabajo puede ser de gran beneficio para quienes se ocupan de 
la investigación teórico-lingüística y lingüística aplicada de las lenguas serbia y española. Para mayor claridad y sistematización, la investigación se divide por áreas temáticas (investigación contrastiva de la lengua serbia y española en el campo de la fonética y fonología; en el campo de la morfosintaxis; en el campo de la lexicología, semántica, fraseología y lexicografía; en el campo de los estudios de traducción; y en el campo del análisis del discurso) y al final de la investigación se encuentra una lista unificada de referencias.

\section{Palabras clave:}

análisis contrastivo, lingüística contrastiva, español, serbio, estudios hispánicos

Summary

\section{OVERVIEW OF CONTRASTIVE RESEARCH OF SERBIAN AND SPANISH IN THE SECOND DECADE OF THE $21^{\text {st }}$ CENTURY}

This paper deals with the publications about the contrastive research of Serbian and Spanish. We rely on previous review papers on this topic (Filipović, 2010; Đuričić and Georgijev, 2015), and supplement them with more recent papers published from 2011 to 2020. Researchers from Serbia and the region contributed a large number of papers that tackle the similarities and differences between these two languages at different language levels. Ninety scientific papers, six doctoral dissertations and two scientific monographs are included in this paper, whose aim is to examine Serbian and Spanish contrastive linguistics topics of interest, their results and differing viewpoints. We have tried to take on a broader perspective and determine which linguistic areas call for more thorough investigation. This paper could be of considerable benefit to those who deal with theoretical and applied linguistics of Serbian and Spanish. For better clarity and systematization, the paper is divided according to thematic areas, and there is an integral list of references at the end.

\section{Key words:}

contrastive analysis, contrastive linguistics, Spanish, Serbian, Hispanic studies 